\title{
PENGARUH BESARAN RUANG DAN JUMLAH MAHASISWA TERHADAP TEMPERATUR DI RUANG KELAS
}

\author{
M. Irham Nurputra ${ }^{1}$, Rosady Mulyadi ${ }^{2}$, Muhammad Taufik Ishak $^{3}$ \\ 1,2,3. Departemen Arsitektur, Fakultas Teknik, Universitas Hasanuddin, \\ Jl. Poros Malino Km. 6, Bontomarannu, Kabupaten Gowa, Sulawesi Selatan \\ Email: muhammadirham@icloud.com
}

\begin{abstract}
Abstrak
Penelitian ini bertujuan untuk meneliti nilai temperatur ruang kelas pada gedung Class Room Fakultas Teknik di kampus Gowa. Selain itu, juga meneliti nilai temperatur yang dipengaruhi oleh pengkondisian besaran ruang dan jumlah mahasiswa pada ruang kelas di gedung Class Room Fakultas Teknik tersebut. Jenis penelitian yang dipakai dalam penelitian ini adalah kuantitatifdeskriptif. Peneliti menggunakan metode pangambilan data dan pengukuran secara langsung dengan alat ukur temperatur yang hasilnya kemudian disajikan dalam bentuk tabel guna membandingkan hasil pengukuran tersebut dengan tabel pengukuran yang telah diberi 'perlakuan'. Dari hasil penelitian ini, peneliti bisa menyimpulkan bahwa nilai temperatur di ruang kelas memiliki angka yang tinggi dan hasil analisis perubahan temperatur yang diakibatkan oleh perubahan besaran ruang kelas dan jumlah mahasiswa di ruang kelas menunjukkan bahwa dengan penambahan jumlah pengguna di ruang kelas akan meningkatkan nilai temperatur, sedangkan dengan penggunaan ruang kelas yang berbeda besarannya menunjukkan penurunan nilai temperatur.
\end{abstract}

Kata kunci: temperatur, ruang kelas, gedung Class Room, kampus Gowa, besaran ruang, jumlah mahasiswa.

\section{Abstract}

\section{Title: Influence of Space and Number of Students on Classroom Temperature}

This study aims to examine the classroom temperature in the Class Room building Faculty of Engineering at Gowa campus. And will focus on classroom temperature influenced by conditioning the dimension of space and the number of students in the Class Room building. The reasearch method used the is quantitative-descriptive. Then collecting data related with the measurement of space, the temperature measured with the instrument then presented in tabular form for later the comparisson with the data from the treated classroom. From the result of this research, concludes that the temperature in the classroom related with changes in the size classroom and the number of students in the classroom indicates that with the addition of the number of users in the classroom will increase the temperature and fewer user in different classrooms shows the decrease the classromm temperature.

Keywords: temperature, classroom, Class Room building, Gowa campus, room size, number of students.

\section{Pendahuluan}

\section{Latar Belakang}

Arsitektur merupakan ilmu mengenai tempat bernaung dari yang paling sederhana hingga yang paling rumit. Arsitektur juga merupakan lingkungan binaan dan lingkungan buatan yang mempunyai bermacam-macam kegunaan, yaitu melindungi manusia dan kegiatan-kegiatannya serta barang miliknya dari elemen-elemen lain seperti manusia, hewan dan iklim. 
Ada 3 sasaran yang seharusnya dipenuhi oleh suatu karya arsitektur. Pertama, bahwa bangunan harus merupakan produk dari suatu kerja seni (work of art). Kedua, bahwa bangunan harus mampu memberikan kenyamanan (baik psikis maupun fisik) kepada penghuninya. Dan yang terakhir, bahwa bangunan perlu hemat terhadap pemakaian energi (Karyono, 1996).

Aspek estetika juga perlu dipenuhi karena arsitektur merupakan bagian dari ilmu seni. Aspek kenyamanan perlu dipenuhi karena arsitektur juga merupakan bagian dari ilmu desain. Sedangkan aspek penghematan energi perlu dipenuhi karena asitektur juga merupakan bagian dari ilmu teknik dan lingkungan. Dalam aspek kenyamanan tercakup di dalamnya adalah kenyamanan psikis dan fisik. Kenyamanan psikis banyak kaitannya dengan kepercayaan, agama, aturan adat dan sebagainya. Aspek ini bersifat personal, kualitatif dan tidak terukur secara kuantitatif. Sedangkan kenyamanan fisik lebih bersifat obyektif dan terukur. Kenyamanan fisik meliputi kenyamanan ruang (spatial comfort), kenyamanan penglihatan (visual comfort), kenyamanan pendengaran (audial comfort) dan kenyamanan suhu (thermal comfort) (Karyono, 1989).

Indikator paling mendasar yang digunakan untuk mengukur kenyamanan thermal adalah suhu ruang/ temperatur ruang. Suhu ruang saja bukanlah indikator valid atau akurat untuk menyatakan kenyamanan thermal. Namun, suhu ruang harus selalu dipertimbangkan dalam kaitannya dengan faktor-faktor lingkungan fisik dan aspek personal lainnya. Ada beberapa faktor yang dapat meningkatkan angka temperatur ruang, dua diantaranya ialah besaran suatu ruang dan banyaknya jumlah pemakai ruang. Besaran ruang meliputi luas ruang dan tinggi plafon yang akan berpengaruh terhadap pertukaran udara per jam atau dikenal dengan istilah Air Change per Hour (ACH), sehingga dapat dikatakan besaran ruang berbanding terbalik dengan temperatur ruang dan pertukaran udara per jam sendiri harus berbanding lurus dengan kenaikan angka temperatur ruang. Karena semakin tinggi temperatur dalam suatu ruangan maka udara di dalam ruangan tersebut harus diganti kembali atau ditukar dengan yang baru. Sedangkan banyaknya jumlah pemakai meliputi tingkat metabolisme manusia, aktivitas dan insulasi pakaian. Metabolisme tiap manusia berbeda-beda, perbedaan tersebut dilihat mulai dari jenis kelamin, suku dan usianya sendiri. Sedangkan aktivitas manusia yang beragam mulai tidur hingga berlari memiliki angka yang berbeda dan akan memberi pemasukan panas terhadap kenaikan temperatur ruangan. Itu semua hanya dilihat berdasarkan satu individu saja. Dengan demikian, hal-hal tersebut akan memberikan pengaruh besar terhadap kenaikan temperatur jika lebih dari satu individu.

Jika melihat penjabaran besaran ruang dan jumlah pemakai di atas, maka jenis bangunan yang sesuai dengan kedua hal tersebut adalah bangunan tempat perkuliahan. Hal ini disebabkan di tempat perkuliahan mengenal perbedaan kelas besar dan kelas kecil, dimana kelas besar akan bersifat umum dan akan diikuti oleh banyak peserta, ditambah lagi jika kelas besar tersebut merupakan kelas mata kuliah wajib. Sedangkan kelas kecil akan diikuti oleh beberapa peserta dikarenakan mata kuliah tersebut merupakan mata kuliah pilihan ataupun mata kuliah yang hanya memiliki alat yang terbatas 
sehingga hanya bisa diikuti oleh beberapa mahasiswa saja.

Oleh sebab itu, hal ini menjadi landasan bagi peneliti dalam melakukan penelitian untuk mengindentifikasi

ketidaknyamanan penghawaan

khususnya pada tingginya angka temperatur ruang kelas di gedung Class Room Fakultas Teknik Universitas Hasanuddin di kampus Gowa dan yang menjadi variabel penelitian adalah pengaruh besaran ruang dan jumlah pemakai terhadap perubahan angka temperatur ruang. Tujuan utama dari penelitian ini adalah untuk mengidentifikasi kondisi perubahan temperatur yang ada di Fakultas Teknik kampus Gowa. Sehingga, hasil penelitian ini dapat menjadi acuan dalam perancangan ataupun renovasi kampus nantinya. Diharapkan dalam pelaksanaan pembangunan tidak terjadi penambahan-penambahan yang meningkatkan ketidaknyamanan dalam bangunan, serta menjadi referensi desain tanpa perlu menggunakan sistem penghawaan mekanis yang boros sebagai upaya pemanfaatan energi.

Pada penelitian ini memiliki beberapa rumusan masalah yang harus dijawab oleh peneliti, antara lain sebagai berikut:

1. Bagaimana kondisi temperatur ruangan kelas di gedung Class Room Fakultas Teknik?

2. Bagaimana pengaruh jumlah mahasiswa di ruang kelas terhadap perubahan angka temperatur di ruang kelas?

3. Bagaimana pengaruh besaran ruang terhadap perubahan angka temperatur dalam ruang kelas?

\section{Metode Penelitian}

Penelitian ini dilakukan oleh peneliti pada akhir bulan Oktober hingga bulan November 2017, yang dilaksanakan di beberapa ruang kelas pada gedung Class Room Fakultas Teknik kampus Gowa.

Alat-alat yang digunakan dalam penelitian ini adalah thermometer (termohydro/Krisbow type KW06281), meteran (5 meter) yang digunakan untuk mengukur secara langsung di lapangan dan software ECOTECH Analysis 2011 digunakan untuk melakukan simulasi data temperatur.

Teknik pengumpulan data yang dilakukan pada penelitian ini memiliki beberapa langkah, sebagai berikut:

1. Pengukuran ruang kelas dan ukuran ventilasi (bukaan)

Angka pengukuran ruang kelas merupakan hasil yang diketahui dengan melihat file CAD ruang kelas dan juga merupakan hasil pengukuran langsung oleh peneliti di lapangan dengan menggunakan meteran. Begitu pula dengan dimensi jendela di ruang kelas, peneliti melakukan pengukuran dengan cara yang sama. Berikut gambar hasil pengukuran:

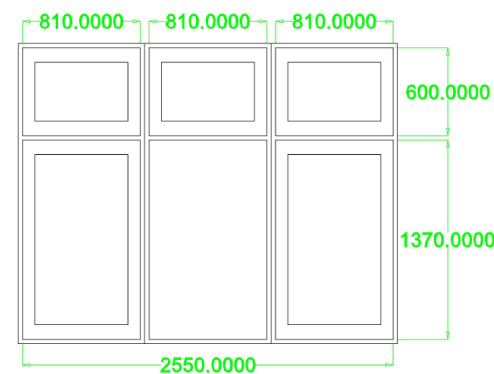

Gambar 1. Ukuran jendela ruang kelas Sumber: Analisis peneliti, 2017

2. Penentuan titik ukur dan pembagian zona 
Pembagian zona akan ditentukan dengan cara membagi 4 tiap ruang kelas secara merata yang diambil berdasarkan pertimbangan akan posisi bukaan. Jadi zona P1 dan P2 sebagai zona yang terjauh dari bukaan (ventilasi), sedangkan zona P3 dan P4 sebagai zona terdekat dengan posisi bukaan (ventilasi). Hal ini dilakukan dengan tujuan untuk mengetahui perubahan temperatur tiap zona dengan melihat posisi bukaan (ventilasi) dimana tiap-tiap zona nantinya akan diberikan perlakuan variabel yang sama pula, yaitu jumlah mahasiswa dan ukuran ruang kelas yang lebih besar. Sedangkan peletakan titik ukur berada tepat di tengah tiap-tiap zona ruang kelas.
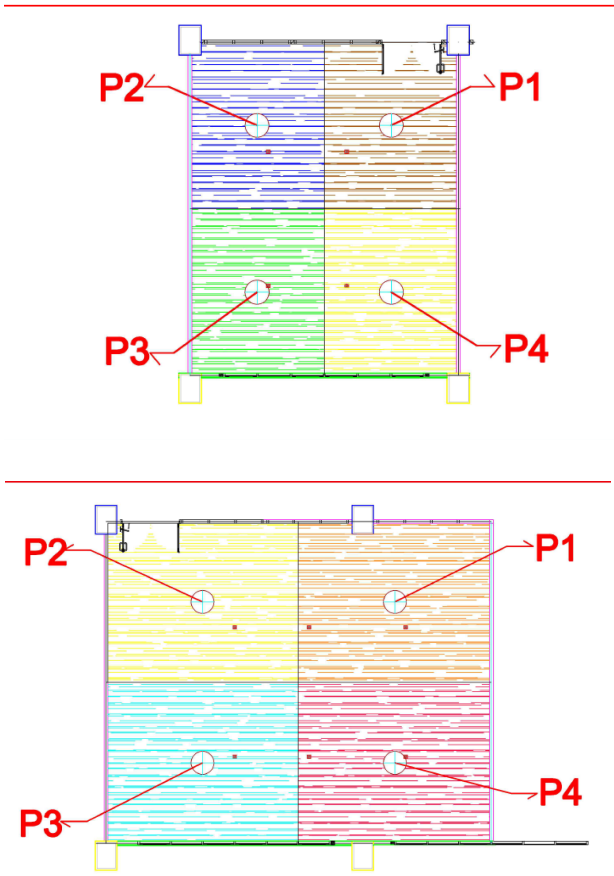

Gambar 2. Titik ukur pada ruang kelas dengan besaran ruang standar (atas) dan titik ukur pada ruang kelas dengan besaran ruang lebih besar (bawah)

Sumber: Analisis peneliti, 2017

3. Pengukuran dengan thermometer (Krisbow type KW06-281)
Thermometer digunakan untuk mengetahui data temperatur ruang tiap-tiap zona di dalam ruang kelas dan pengukuran temperatur di luar kelas. Kemudian hasil angka yang ditunjukkan akan dicatat dan kemudian dianalisis.

Analisis data dilakukan dengan cara membandingkan data yang diambil dari ruang kelas yang telah diberikan variabel lainnya. Jadi, awalnya peneliti akan mengambil data angka temperatur pada tiap titik di ruang kelas dan di luar kelas dalam 3 periode waktu (pagi, siang dan sore hari) saat ruang kelas dengan keadaan tidak berpenghuni dan berada pada ruang kelas yang standar. Kemudian hasilnya akan dibandingkan dengan data angka pengukuran pada ruang kelas ukuran standar yang diberikan variabel jumlah mahasiswa dan selanjutnya dibandingkan dengan penggunaan ruang kelas yang berukuran lebih besar.

\section{Simulasi dengan software ECOTECH} Analysis

Software ECOTECH digunakan untuk memperoleh data nilai temperatur terhadap penggunaan ruang kelas yang besaran ruangnya berbeda, terutama perbedaan ukuran ruang kelas di lapangan dan ruang kelas yang didesain menggunakan software ECOTECH.

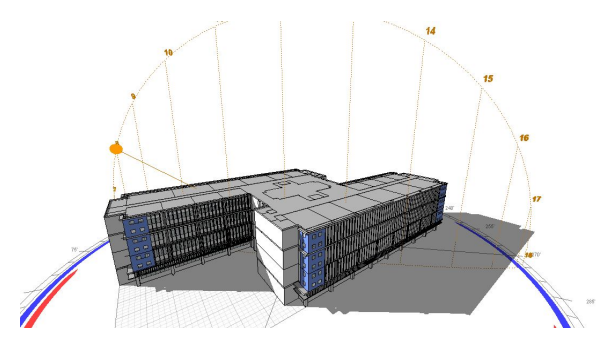

Gambar 3. Desain bangunan Classroom pada ECOTECH

Sumber: Analisis peneliti, 2017

Penelitian ini melakukan observasi dan analisis terhadap suhu ruang kuliah di 
gedung Class Room Fakultas Teknik kampus Gowa. Jenis penelitian yang dipilih dan dipakai peneliti adalah kuantitatif-deskriptif. Peneliti menggunakan metode pengambilan data pengukuran secara langsung dengan alat ukur temperatur yang kemudian disajikan dalam bentuk tabel dan membandingkan hasil pengukuran tersebut dengan tabel pengukuran yang telah diberi 'perlakuan'. Selanjutnya, peneliti memasukkan dan mengubah data pengukuran langsung ke dalam program simulasi untuk memperkuat data pengukuran langsung sehingga peneliti dapat mengambil kesimpulan mengenai perubahan suhu di ruang kelas.

Berikut adalah diagram alur yang digunakan peneliti dalam penelitiaan ini.

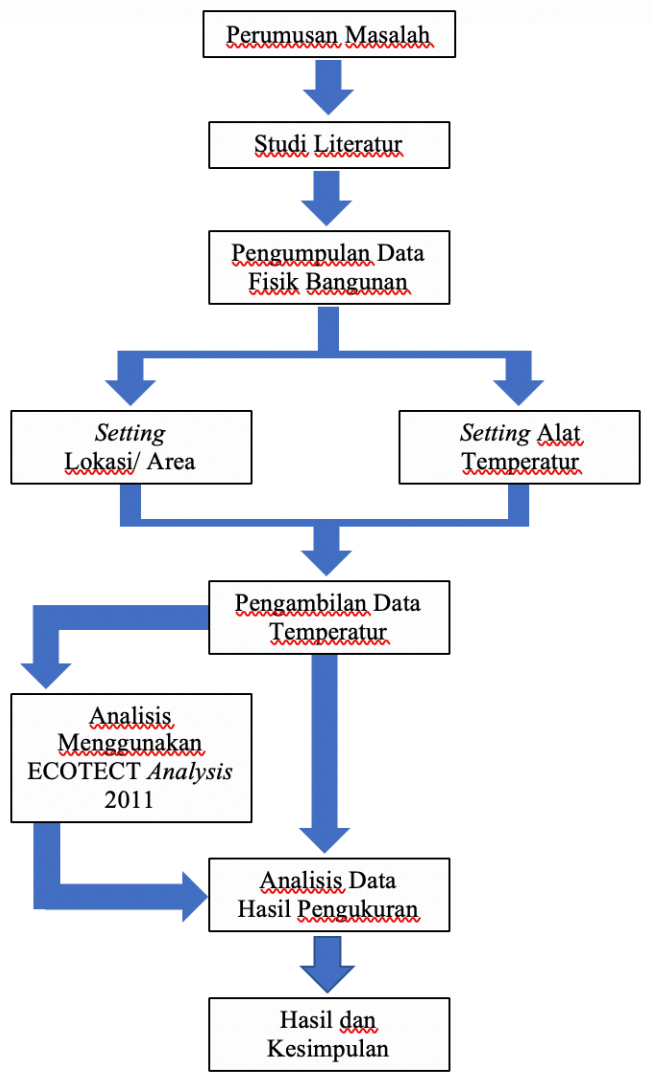

Gambar 4. Diagram alur penelitian Sumber: Analisis peneliti, 2017

\section{Hasil dan Pembahasan}

Berdasarkan observasi awal yang dilakukan oleh peneliti, baik yang dilihat maupun dirasakan langsung, kondisi awal ruang-ruang kelas yang ada di gedung Class Room (CR) ini cukup panas dan lembab sehingga mahasiswa yang melaksanakan kuliah lebih memlilih ruang-ruang yang telah dipasang Air Conditioner (AC) untuk menghindari ketidaknyamanan dalam proses belajar-mengajar. Luas bangunan CR sebesar $2609 \mathrm{~m}^{2}$. Ruang kelas pada bangunan CR memiliki 2 tipe kelas, kelas dengan kapasitas 40 orang dengan dimensi 7.2 meter x 9 meter dan kelas dengan kapasitas 80 orang dengan dimensi 7.2 meter $\mathrm{x} 10.8$ meter. Peneliti mengambil delapan ruang kelas untuk penelitian ini, empat ruang di lantai 1 dan empat ruang di lantai 2. Dua ruang kelas dengan kapasitas 40 orang dan dua ruang kelas dengan kapasitas 80 orang pada tiap lantainya.

\section{Pengukuran Ruang Kelas dengan Kapasitas 40 Orang (7.2 meter $x 9$ meter)}

Pengukuran temperatur dilakukan di ruang kelas pada empat titik ukur dan pada tiga periode waktu (pagi, siang dan sore hari). Selanjutnya nilai keempat titik ukur pada ruang kelas dihitung dengan matematika sederhana untuk memperoleh nilai rata-rata temperatur dalam satu periode, seperti dalam tabel berikut: 
Tabel 1. Nilai rata-rata temperatur ruang kelas

\begin{tabular}{|c|c|c|c|c|}
\hline \multirow{2}{*}{ Waktu } & \multirow[t]{2}{*}{$\begin{array}{c}\text { Keadaan } \\
\text { Ruang Kelas }\end{array}$} & \multicolumn{2}{|c|}{$\begin{array}{l}\text { Rata -Rata Temperatur } \\
\text { di ruang kelas }\end{array}$} & \multirow[t]{2}{*}{$\begin{array}{c}\text { Temperatur di } \\
\text { Luar Ruang Kelas }\end{array}$} \\
\hline & & $\mathrm{T} 1$ & T2 & \\
\hline \multirow[t]{2}{*}{ Pagi hari } & Tertutup & 28.5 & 29 & 28.5 \\
\hline & Terbuka & 29 & 28.75 & 29.5 \\
\hline \multirow{2}{*}{$\begin{array}{l}\text { Siang } \\
\text { hari }\end{array}$} & Tertutup & 30.5 & 31 & 31.5 \\
\hline & Terbuka & 29.5 & 29.5 & 32.5 \\
\hline \multirow[t]{2}{*}{ Sore hari } & Tertutup & 29.25 & 29.5 & 29.5 \\
\hline & Terbuka & 29.5 & 29.5 & 29.5 \\
\hline
\end{tabular}

Sumber: Analisis peneliti, 2017

Berdasarkan tabel-tabel yang disajikan di atas, dapat disimpulkan bahwa angka temperatur ruang kelas paling tinggi terjadi ketika ruang kelas tertutup pada saat siang hari, yang memiliki angka temperatur $31^{\circ} \mathrm{C}$ dan angka temperatur ruang kelas paling tinggi ketika ruang terbuka juga terjadi saat siang hari dengan angka sebesar $29.5^{\circ} \mathrm{C}$.

\section{Pengukuran Ruang kelas yang Terisi Pengguna}

Nilai temperatur yang terjadi pada ruang kelas yang mengalami perlakuan terisi pengguna mulai dari 10 orang, 20 orang, 30 orang dan hingga yang tidak terisi dapat dilihat pada tabel 2, 3 dan 4 berikut.

Tabel 2. Nilai rata-rata temperatur ruang kelas saat berpengguna 10 orang

\begin{tabular}{|c|c|c|c|c|}
\hline \multirow{2}{*}{ Waktu } & \multirow[t]{2}{*}{$\begin{array}{c}\text { Keadaan } \\
\text { Ruang Kelas }\end{array}$} & \multicolumn{2}{|c|}{$\begin{array}{c}\text { Rata -Rata Temperatur } \\
\text { di ruang kelas }\end{array}$} & \multirow[t]{2}{*}{$\begin{array}{c}\text { Temperatur di } \\
\text { Luar Ruang Kelas }\end{array}$} \\
\hline & & T1 & T2 & \\
\hline \multirow[t]{2}{*}{ Pagi hari } & Tertutup & 29.5 & 30 & 28.5 \\
\hline & Terbuka & 29.5 & 29.5 & 29.5 \\
\hline \multirow{2}{*}{$\begin{array}{l}\text { Siang } \\
\text { hari }\end{array}$} & Tertutup & 31.5 & 31.75 & 31.5 \\
\hline & Terbuka & 30.5 & 30 & 31.5 \\
\hline \multirow[t]{2}{*}{ Sore hari } & Tertutup & 31 & 31.75 & 31.5 \\
\hline & Terbuka & 30.5 & 29.75 & 29.5 \\
\hline
\end{tabular}

Sumber: Analisis peneliti, 2017
Tabel 3. Nilai rata-rata temperatur ruang kelas saat berpengguna 20 orang

\begin{tabular}{|c|c|c|c|c|}
\hline \multirow{2}{*}{ Waktu } & \multirow[t]{2}{*}{$\begin{array}{c}\text { Keadaan } \\
\text { Ruang Kelas }\end{array}$} & \multicolumn{2}{|c|}{$\begin{array}{c}\text { Rata -Rata Temperatur } \\
\text { di ruang kelas }\end{array}$} & \multirow[t]{2}{*}{$\begin{array}{c}\text { Temperatur di } \\
\text { Luar Ruang Kelas }\end{array}$} \\
\hline & & $\mathrm{T} 1$ & $\mathrm{~T} 2$ & \\
\hline \multirow[t]{2}{*}{ Pagi hari } & Tertutup & 30 & 30.5 & 29.5 \\
\hline & Terbuka & 29.75 & 30 & 29.5 \\
\hline \multirow{2}{*}{$\begin{array}{l}\text { Siang } \\
\text { hari }\end{array}$} & Tertutup & 32.5 & 33.25 & 31.5 \\
\hline & Terbuka & 32 & 32 & 32.5 \\
\hline \multirow[t]{2}{*}{ Sore hari } & Tertutup & 30.75 & 31.25 & 30.5 \\
\hline & Terbuka & 30.5 & 30 & 29.5 \\
\hline
\end{tabular}

Sumber: Analisis peneliti, 2017

Tabel 4. Nilai rata-rata temperatur ruang kelas saat berpengguna 30 orang

\begin{tabular}{|c|c|c|c|c|}
\hline \multirow{2}{*}{ Waktu } & \multirow[t]{2}{*}{$\begin{array}{c}\text { Keadaan } \\
\text { Ruang Kelas }\end{array}$} & \multicolumn{2}{|c|}{$\begin{array}{l}\text { Rata -Rata Temperatur } \\
\text { di ruang kelas }\end{array}$} & \multirow[t]{2}{*}{$\begin{array}{c}\text { Temperatur di } \\
\text { Luar Ruang Kelas }\end{array}$} \\
\hline & & $\mathrm{T} 1$ & T2 & \\
\hline \multirow[t]{2}{*}{ Pagi hari } & Tertutup & 31.75 & 32.25 & 30.5 \\
\hline & Terbuka & 31.5 & 32 & 31.5 \\
\hline \multirow{2}{*}{$\begin{array}{l}\text { Siang } \\
\text { hari }\end{array}$} & Tertutup & 32 & 32.5 & 32.5 \\
\hline & Terbuka & 33.5 & 33.5 & 33.5 \\
\hline \multirow[t]{2}{*}{ Sore hari } & Tertutup & 32 & 32.5 & 30.5 \\
\hline & Terbuka & 32 & 31.5 & 29.5 \\
\hline
\end{tabular}

Sumber: Analisis peneliti, 2017

Dari data hasil pengukuran di atas ketika ruang kelas dalam kondisi tertutup memiliki suhu paling rendah terjadi saat ruangan kosong dengan nilai temperatur $29.4^{\circ} \mathrm{C}$ dan memiliki suhu tertinggi terjadi saat ruangan terisi 30 orang dengan nilai temperatur mencapai $32.5^{\circ} \mathrm{C}$. Sedangkan saat ruang kelas dalam kondisi terbuka suhu terendah terjadi saat ruangan kosong dengan nilai temperatur $29.25^{\circ} \mathrm{C}$ dan memiliki suhu tertinggi terjadi saat ruangan terisi 30 orang dengan nilai temperatur mencapai $32.3^{\circ} \mathrm{C}$, seperti yang ditunjukkan pada tabel 5 dan gambar 5 berikut. 
Tabel 5. Nilai rata-rata temperatur ruang kelas yang dipengaruhi jumlah pengguna

\begin{tabular}{|c|c|c|c|c|c|}
\hline \multirow{2}{*}{$\begin{array}{c}\text { Jumlah } \\
\text { Mahasiswa }\end{array}$} & \multirow{2}{*}{$\begin{array}{c}\text { Keadaan Ruang } \\
\text { Kelas }\end{array}$} & \multicolumn{2}{|c|}{ Temperatur ( } & \multicolumn{2}{|c|}{$\begin{array}{l}\text { Rata-Rata } \\
\text { temperatur }\end{array}$} \\
\hline & & Max & Min & $\mathrm{T} 1$ & $\mathrm{~T} 2$ \\
\hline \multirow[t]{2}{*}{ Kosong } & Tertutup & 31 & 28.5 & 29.4 & 29.8 \\
\hline & Terbuka & 29.5 & 28 & 29.3 & 29.25 \\
\hline \multirow[t]{2}{*}{10 Orang } & Tertutup & 31.75 & 29.5 & 30.6 & 31 \\
\hline & Terbuka & 30.5 & 29.5 & 30 & 29.75 \\
\hline \multirow[t]{2}{*}{20 Orang } & Tertutup & 33.25 & 30 & 31 & 31.5 \\
\hline & Terbuka & 32 & 29.75 & 30.75 & 30.5 \\
\hline \multirow[t]{2}{*}{30 Orang } & Tertutup & 32.5 & 31.75 & 32 & 32.5 \\
\hline & Terbuka & 33.5 & 31.5 & 31.9 & 32.3 \\
\hline
\end{tabular}

Sumber: Analisis peneliti, 2017

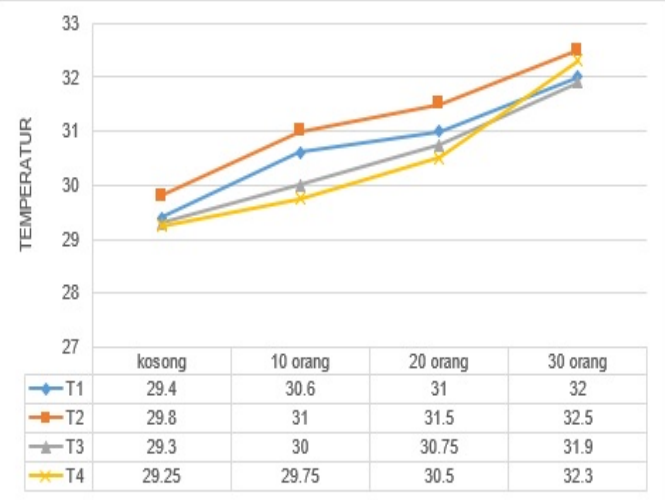

Gambar 5. Grafik perbandingan angka perubahan temperatur bedasarkan jumlah pengguna atau mahasiswa

Sumber: Analisis peneliti, 2017

Dari tabel di atas kita dapat melihat anomali angka pada suhu ruang tertinggi untuk 30 orang, dimana nilai temperatur saat ventilasi terbuka jauh lebih tinggi dibandingkan nilai temperatur saat ventilasi tertutup. Hal ini disebabkan oleh nilai temperatur di luar kelas yang berbeda saat pengukuran di ruang kelas ketika ventilasi tertutup dan terbuka, hal ini dapat dilihat lebih jelas pada tabel 4 yang memperlihatkan suhu ruang kelas di siang hari.

Berdasarkan tabel dan gambar grafik di atas dapat disimpulkan semakin banyak pengguna ruang kelas akan meningkatkan nilai temperatur ruang kelas tersebut.
Pengukuran Ruang Kelas dengan Kapasitas 80 orang (7.2 meter x 10.8 meter)

Hasil pengukuran temperatur di ruang kelas dengan besaran yang berbeda dilakukan pada ruang kelas berkapasitas 80 orang dan dilakukan pengukuran pada empat titik ukur pada tiga periode waktu (pagi, siang dan sore hari). Selanjutnya nilai pada keempat titik ukur pada ruang kelas diperhitungkan dengan matematika sederhana untuk memperoleh nilai rata-rata temperatur dalam satu periode, seperti dalam tabel berikut.

Tabel 6. Nilai rata-rata temperatur ruang kelas berkapasitas 80 orang

\begin{tabular}{|c|c|c|c|c|}
\hline \multirow{2}{*}{ Waktu } & $\begin{array}{c}\text { Keadaan } \\
\text { Ruang Kelas }\end{array}$ & \multicolumn{2}{|c|}{$\begin{array}{r}\text { Rata -Rata Temperatur } \\
\text { di ruang kelas }\end{array}$} & $\begin{array}{c}\text { Temperatur di } \\
\text { luar ruang kelas }\end{array}$ \\
\cline { 4 - 5 } & T1 & T2 & \\
\hline \multirow{2}{*}{ Pagi hari } & Tertutup & 28.5 & 28.5 & 28 \\
\cline { 2 - 5 } & Terbuka & 28.37 & 28.25 & 29 \\
\hline \multirow{2}{*}{$\begin{array}{c}\text { Siang } \\
\text { hari }\end{array}$} & Tertutup & 29.5 & 29.75 & 31.5 \\
\cline { 2 - 5 } & Terbuka & 30.5 & 30.5 & 33.5 \\
\hline \multirow{2}{*}{\begin{tabular}{c} 
Sore hari \\
\cline { 2 - 4 }
\end{tabular}} & Tertutup & 29.25 & 30.25 & 31.5 \\
\cline { 2 - 5 } & Terbuka & 29.37 & 29.25 & 29.5 \\
\hline
\end{tabular}

Sumber: Analisis peneliti, 2017

Berdasarkan tabel di atas dapat disimpulkan bahwa ruang kelas berkapasitas 40 orang memiliki nilai temperatur yang lebih tinggi dibanding ruang kelas berkapasitas 80 orang, walaupun nilai temperatur di luar ruang kelas berkapasitas 80 orang jauh lebih tinggi dibandingkan ruang kelas berkapasitas 40 orang. Namun, nilai temperatur di ruang kelas berkapasitas 80 orang ini tidak mengalami kenaikan yang tinggi. Dengan demikian, peneliti mengambil kesimpulan semakin besar ruang kelas maka akan menghambat nilai temperatur ruang kelas untuk naik lebih tinggi lagi. Hal ini dapat dilihat lebih jelas dalam gambar grafik perbandingan berikut. 


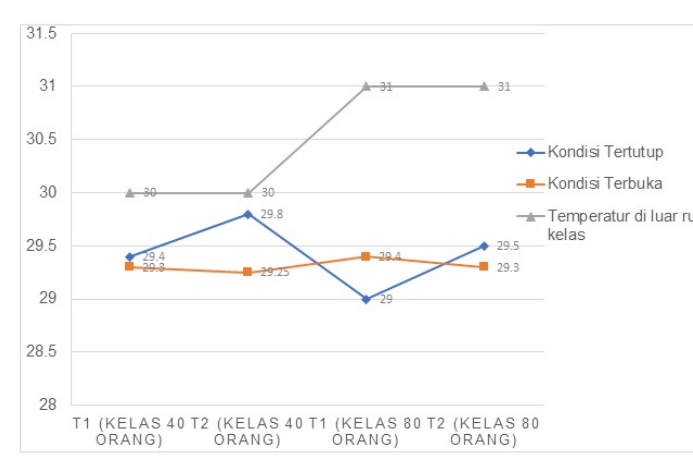

Gambar 6. Grafik perbandingan angka temperatur antara ruang kelas berkapasitas 40 orang dan 80 orang

Sumber: Analisis peneliti, 2017

\section{Simulasi Nilai Temperatur Menggunakan Software ECOTECH Analysis 2011}

Simulasi ini dilakukan dengan mengubah ketinggian ruangan, dimana ketinggian awal ruangan hanya 3.1 meter kemudian ditambah 1.1 meter sehingga menjadi 4.2 meter. Hal ini dilakukan peneliti dengan tujuan melihat perubahan nilai temperatur jika tinggi ruangan dipertinggi dari kondisi awal. Berdasarkan hasil simulasi maka diperoleh nilai temperatur sebagai berikut.

Tabel 7. Hasil simulasi nilai temperatur ruang kelas menggunakan software ECOTECH analysis 2011 (ruang kelas berkapasitas 40 orang \& 80 orang)

\begin{tabular}{|rc|c|c|}
\hline HOUR & $\begin{array}{c}\text { INSIDE } \\
\text { (C) }\end{array}$ & $\begin{array}{c}\text { OUTSIDE } \\
\text { (C) }\end{array}$ & $\begin{array}{c}\text { TEMP.DIF } \\
\text { (C) }\end{array}$ \\
\hline & & -- & - \\
\hline 00 & 24.9 & 23.4 & 1.5 \\
\hline 01 & 24.8 & 22.8 & 2.0 \\
\hline 02 & 24.7 & 22.5 & 2.2 \\
\hline 03 & 24.6 & 22.2 & 2.4 \\
\hline 04 & 24.5 & 22.0 & 2.5 \\
\hline 05 & 24.5 & 21.9 & 2.6 \\
\hline 06 & 26.2 & 23.0 & 3.2 \\
\hline 07 & 28.3 & 24.8 & 3.5 \\
\hline 08 & 30.4 & 26.7 & 3.7 \\
\hline 09 & 31.9 & 28.5 & 3.4 \\
\hline 10 & 32.9 & 30.2 & 2.7 \\
\hline 11 & 34.3 & 31.4 & 2.9 \\
\hline 12 & 34.7 & 32.2 & 2.5 \\
\hline 13 & 33.7 & 32.7 & 1.0 \\
\hline 14 & 32.5 & 32.9 & -0.4 \\
\hline 15 & 31.4 & 32.4 & -1.0 \\
\hline 16 & 29.7 & 31.5 & -1.8 \\
\hline 17 & 27.3 & 30.1 & -2.8 \\
\hline 18 & 26.4 & 29.4 & -3.0 \\
\hline
\end{tabular}

\begin{tabular}{|cc|c|c|}
\hline HOUR & $\begin{array}{c}\text { INSIDE } \\
\text { (C) }\end{array}$ & $\begin{array}{c}\text { OUTSIDE } \\
\text { (C) }\end{array}$ & $\begin{array}{c}\text { TEMP.DIF } \\
\text { (C) }\end{array}$ \\
\hline-- & - & - & - \\
\hline 00 & 26.7 & 23.4 & 3.3 \\
01 & 26.6 & 22.8 & 3.8 \\
\hline 02 & 26.5 & 22.5 & 4.0 \\
\hline 03 & 26.4 & 22.2 & 4.2 \\
\hline 04 & 26.3 & 22.0 & 4.3 \\
\hline 05 & 26.3 & 21.9 & 4.4 \\
\hline 06 & 27.2 & 23.0 & 4.2 \\
\hline 07 & 28.4 & 24.8 & 3.6 \\
\hline 08 & 29.6 & 26.7 & 2.9 \\
\hline 09 & 30.6 & 28.5 & 2.1 \\
\hline 10 & 31.3 & 30.2 & 1.1 \\
\hline 11 & 32.4 & 31.4 & 1.0 \\
\hline 12 & 32.8 & 32.2 & 0.6 \\
\hline 13 & 32.4 & 32.7 & -0.3 \\
\hline 14 & 31.8 & 32.9 & -1.1 \\
\hline 15 & 31.3 & 32.4 & -1.1 \\
\hline 16 & 30.3 & 31.5 & -1.2 \\
\hline 17 & 28.8 & 30.1 & -1.3 \\
\hline 18 & 28.2 & 29.4 & -1.2 \\
\hline
\end{tabular}

Sumber: Analisis peneliti, 2017

\section{Kesimpulan}

Berdasarkan hasil pengukuran dan analisis data pengukuran pada ruang kelas gedung Class Room Fakultas Teknik Unhas dapat ditarik kesimpulan sebagai berikut:

1. Hasil pengukuran temperatur dan analisis data dalam ruang kelas gedung Class Room yang dilakukan pada empat titik di ruang kelas dalam waktu 3 periode (pagi, siang dan sore hari) memiliki angka temperatur yang tinggi. Nilai rata-rata temperatur pada pengkondisian ventilasi tertutup dalam sehari mencapai angka $29.4^{\circ} \mathrm{C}$ hingga $29.8^{\circ} \mathrm{C}$, rata-rata temperatur udara pada pengkondisian ventilasi terbuka mencapai angka temperatur $29.3^{\circ} \mathrm{C}$ hingga $29.25^{\circ} \mathrm{C}$.

2. Berdasarkan hasil pengkuran temperatur dan analisis data dalam ruang kelas gedung Class Room yang dipengaruhi oleh jumlah mahasiswa (10 orang, 20 orang dan 30 orang) yang berada dalam ruang kelas dapat disimpulkan ketika ruang kelas diberi penambahan jumlah pengguna akan mengalami kenaikan nilai temperatur di ruang kelas tersebut. Dengan perubahan nilai temperatur untuk ruang kelas dengan ventilasi tertutup dan penambahan jumlah 10 orang 
dalam ruangan memiliki kenaikan angka temperatur sebanyak $0.7^{\circ} \mathrm{C}$ sampai $1.2^{\circ} \mathrm{C}$ dengan angka temperatur tertinggi mencapai angka $31.7^{\circ} \mathrm{C}$. Untuk penambahan jumlah 20 orang dalam ruangan memiliki kenaikan angka temperatur dari $1.6^{\circ} \mathrm{C}$ hingga $1.9^{\circ} \mathrm{C}$ dengan angka temperatur tertinggi mencapai angka $33.25^{\circ} \mathrm{C}$. Untuk penambahan jumlah 30 orang dalam ruangan memiliki kenaikan angka temperatur dari $2.6^{\circ} \mathrm{C}$ hingga $3.05^{\circ} \mathrm{C}$ dengan angka temperatur tertinggi mencapai angka $33.5^{\circ} \mathrm{C}$. Sedangkan untuk ruang kelas dengan ventilasi terbuka dan penambahan jumlah 10 orang dalam ruangan memiliki kenaikan angka temperatur sebanyak $0.5^{\circ} \mathrm{C}$ hingga $0.7^{\circ} \mathrm{C}$ dengan angka temperatur tertinggi mencapai angka $30.5^{\circ} \mathrm{C}$. Untuk penambahan jumlah 20 orang dalam ruangan memiliki kenaikan angka temperatur dari $1.25^{\circ} \mathrm{C}$ hingga $1.45^{\circ} \mathrm{C}$ dengan angka temperatur tertinggi mencapai angka $32^{\circ} \mathrm{C}$. Untuk penambahan jumlah 30 orang dalam ruangan memiliki kenaikan angka temperatur dari $2.6^{\circ} \mathrm{C}$ hingga $3.05^{\circ} \mathrm{C}$ dengan angka temperatur tertinggi mencapai angka $33.5^{\circ} \mathrm{C}$.

3. Adanya pengaruh penggunaan ruang kelas yang lebih besar terhadap angka temperatur ruang kelas gedung Class Room ditunjukkan dengan penggunaan ruang kelas yang jauh lebih besar menyebabkan perbedaan angka temperatur ruang kelas, dengan perubahan nilai temperatur udara dalam ruang kelas dengan pengkondisian ventilasi tertutup mengalami perubahan sebesar $0.1^{\circ} \mathrm{C}$ hingga $0.4^{\circ} \mathrm{C}$ dengan angka temperatur ruang kelas tertinggi mencapai angka $30.25^{\circ} \mathrm{C}$.
Sedangkan dengan pengkondisian ventilasi terbuka mengalami perubahan sebesar $0.25^{\circ} \mathrm{C}$ hingga $0.4^{\circ} \mathrm{C}$ dengan angka temperatur ruang kelas tertinggi mencapai angka $30.5^{\circ} \mathrm{C}$. Dengan demikian penggunaan ruang kelas yang lebih besar dapat menghambat naiknya nilai temperatur ruang kelas.

Saran yang diberikan kepada para pembaca yang ingin meneliti hal yang sama dan melanjutkan penelitian ini di tempat yang sama adalah perlu mencari strategi terbaik agar temperatur udara yang nyaman dalam ruangan bisa merata di seluruh ruangan kuliah. Pada daerah di sekitar ruang kelas perlu ditambahkan elemenelemen yang dapat mereduksi temperatur udara luar yang panas, seperti vegetasi karena efek peneduh dan penyaring dari elemen vegetasi tersebut dapat mereduksi temperatur udara dari luar.

\section{Daftar Pustaka/ Referensi}

Karyono, T.H. (1996). Arsitektur, ilmu pengetahuan dan energi. Konstruksi, Mei, hal. 22.

Karyono, T.H. (1989). Solar energy and architecture: A study of passive solar design for hospital wards in Indonesia. (MA Dissertation, School of Advanced Architectural Studies, University of York, UK, 1989). 